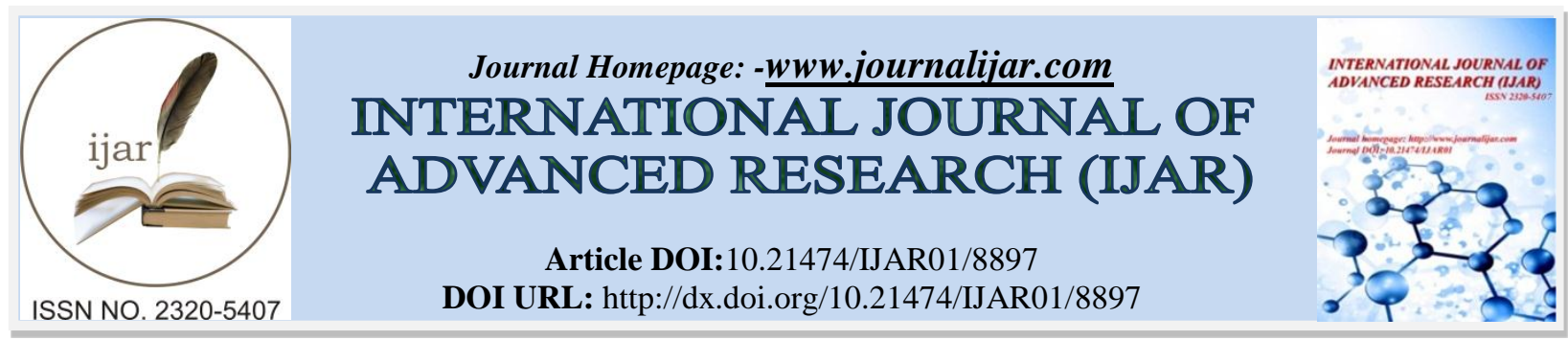

RESEARCH ARTICLE

\title{
ROLE OF CRM IN ERP ESPECIALLY FOR SELECTED ENGINEERING COMPANIES IN AHMEDABAD.
}

Dr. Mehul Patel ${ }^{1}$ and Mr. Mitesh Patel ${ }^{2}$.

1. Assistant Professor, C.P.Patel \& F.H.Shah Commerce College, Anand.

2. C.P.Patel \& F.H.Shah Commerce College, Anand.

\section{Manuscript Info}

Manuscript History

Received: 12 February 2019

Final Accepted: 14 March 2019

Published: April 2019

Key words:-

CRM, ERP, Pearson Correlations, IQ,

SU, A and CRMBF.

\section{Abstract}

The purpose of this investigation is to identify the awareness of CRM in ERP and essential components of CRM-ERP integration and how it deals with HR concerns. CRM: The Business Focus factor and information quality of ERP solution, system quality of ERP solution, system use of ERP solution and appropriateness of ERP solutions in context to Engineering companies of Ahmedabad City. The total CRMERP integration oriented Engineering companies are 58 in Ahmedabad. The selection of 15 companies is made possible on the basis of five zones of Ahmedabad City. The source of data is primary and secondary. The primary data are collected through structured questionnaire administered to the respondents in person and through email; scale reliability test and Pearson correlations test are conducted as statistical tests for achieving the objectives.

Copy Right, IJAR, 2019,. All rights reserved.

\section{Introduction:-}

Enterprise Resource Planning is business management software, typically a suite of integrated applications - that a company can use to collect, store, manage and interpret data from many business activities, including: product planning, cost. Manufacturing or service delivery, marketing and sales. This phenomenon in software industry is inevitable in business world in 21st century. The integration of ERP with customer relationship management gives better firm performance and smooth management practices. Most of the organizations either SMEs or large scale companies have integration interfaces between ERP and CRM systems for the exchange of customer and sales data. In recent years there has been a blurring of the distinctions between ERP and CRM systems. Most ERP systems have expanded to also include basic functionality for CRM and Management Information Systems (MIS). Similarly, CRM systems now include much general ERP functionality. The aims of this investigation to identify the essential components of Supply Chain Information System and their relations with CRM: The business focus in context to selected Engineering companies of Ahmedabad City.

\subsection{Review of Literature}

CRM: The Business Focus: A restricted view of Customer Relationship Management would be database marketing focusing on how promotional marketing is linked to database management tools. A more widely accepted idea Cities that it is the application of technology that emphasizes on individual or one-to-one relationship with customers by integrating database knowledge with the long term prospects of growth and customer loyalty. Managing a successful CRM implementation requires an integrated and balanced approach to technology, process, and people (Chen, J. In

Corresponding Author:-Dr. Mehul Patel.

Address:-Assistant Professor, C.P.Patel \& F.H.Shah Commerce College, Anand. 
jazz, pop vich, K., 2001). CRM is an IT enabled business strategy, the outcomes of which optimize profitability, revenue and customer satisfaction by organizing around customer segments fostering customer-satisfying behavior and implementing a customer central process A detailed analysis of available definitions in the domain of CRM helps us compile the following definition- Customer Relationship Management is a comprehensive business strategy to empower the internal functioning of an organization with the aim to identify, acquire, deliver, develop and retain customers. With the use of ever-changing technology, this process seeks to integrate various functions of an organization, such that it becomes effective and efficient in the long run. This enables the organization to have a high customer share and market share to gain a long term competitive advantage. CRM attempts to provide a strategic bridge between information technology and marketing strategies aimed at building long-term relationships and profitability. This requires 'information-intensive strategies' (Glazer, R., 2002). (Reinartz, W., Kraft, M. and Wayne D. Hoyer, 2004) The strategy development process: This process requires a dual focus on the organization's business strategy and its customer strategy. The value creation process: The value creation process transforms the outputs of the strategy development process into programs that both extract and deliver value. The three key elements of the value creation process are determining what value the company can provide to its customer; determining what value the company can receive from its customers and by successfully managing this value exchange, which involves a process of co-creation or co-production, maximizing the lifetime value of desirable customer segments. The multi-channel integration process: The multi-channel integration process is arguably one of the most important processes in CRM because it takes the outputs of the business strategy and value creation processes and translates them into value-adding activities with customers. The Information Management process: The information management process is concerned with the collection, collation, and use of customer data and information from all customer contact points to generate customer insight and appropriate marketing responses. Morgan and Hunt, (1994 ;) A Kothandaraman and Wilson, (2000)119 found out that, the use of CRM strategies and tactics serve as one of the major driving forces behind many companies' efforts to create superior value for their customers and generate a long-term revenue stream for themselves. Since the creation of a superior value for customers is needed to generate and maintain a sustainable competitive advantage. At the same time that CRM has increased their ability to organize, store, process, and analyze data from their own internal business activities as well as from external sources. Improved computer technologies, combined with more powerful software, provided by banks that specialize in CRM applications, have resulted in an ability to use data in ways never before possible in developing competitive strategies.

\subsection{Significance Of The Study}

The study contributes to the knowledge of the researchers as well as provides much-needed details to the software designers. The findings of the present study would be of use to large and small manufacturers about the conception and perception about various software.

\subsection{Research Objectives}

1. To examine the relationship between CRM: The Business Focus factor and information quality of ERP solution in context to Engineering companies of Ahmedabad City.

2. To examine the relationship between CRM: The Business Focus factor and system quality of ERP solution in context to Engineering companies of Ahmedabad City.

3. To study the relationship between CRM: The Business Focus factor and system use of ERP solution in context to Engineering companies of Ahmedabad City.

4. To study the relationship between CRM: The Business Focus factor and appropriateness of ERP solution in context to Engineering companies of Ahmedabad City.

\subsection{Analysis}

\subsection{Scale Reliability Test}

In this study, all the five factors are tested for their scale reliability means on knowing internal consistency of variables.

\subsubsection{Scale Reliability Test: Information Quality (IQ)}

Scale reliability of IQ is tested with validity of cases, exclusive in nature and number of variables. The following table-5.1 describes the results on the same. 


\begin{tabular}{|l|l|r|r|}
\hline \multirow{3}{*}{ Cases } & Valid & 372 & 100.0 \\
\cline { 2 - 4 } & Excluded $^{\mathrm{a}}$ & 0 & 0 \\
\cline { 2 - 4 } & Total & 372 & 100.0 \\
\hline
\end{tabular}

a. List wise deletion based on all variables in the procedure.

Table 5.1:- indicates the results on 372 valid respondents and its $100 \%$ validity in form of case processing summary.

\begin{tabular}{|c|c|c|}
\hline \multicolumn{3}{|c|}{ Reliability Statistics(Table-5.2) } \\
\hline Cronbach's Alpha & & $\mathrm{N}$ of Items \\
\hline 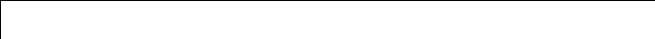 & 0.826 & 12 \\
\hline
\end{tabular}

Table 5.2:- indicates that $\mathrm{N}$ is 12 and Cronbach alpha is 0.826 It means $82.6 \%$ internal consistency amongst IQ1-12.

\subsubsection{Scale Reliability Test: System Quality (SQ)}

\begin{tabular}{|l|l|r|r|}
\hline \multicolumn{4}{|c|}{ Case Processing Summary(Table-5.3) } \\
\hline \multicolumn{2}{|l|}{} & N & $\%$ \\
\hline Cases & Valid & 372 & 100.0 \\
\hline & Excluded $^{\mathrm{a}}$ & 0 & 0 \\
\hline & Total & 372 & 100.0 \\
\hline \multicolumn{2}{|l|}{} \\
\hline
\end{tabular}

Table 5.3:-indicates the results on 372 valid respondents and its $100 \%$ validity in form of case processing summary.

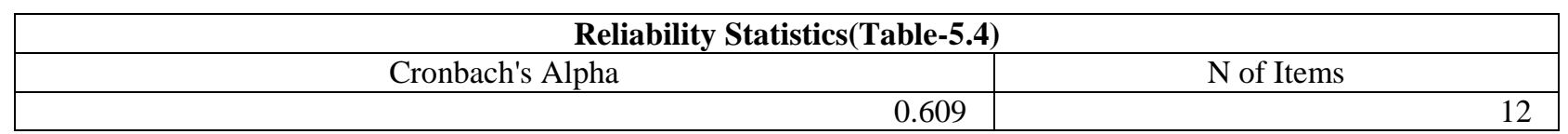

Table 5.4:-indicates that $\mathrm{N}$ is 12 and Cronbach alpha is 0.609It means 60.9\% internal consistency amongst SQ1-12.

5.1.3 Scale Reliability Test: System Use (SU)

\begin{tabular}{|c|c|c|c|}
\hline \multicolumn{4}{|c|}{ Case Processing Summary(Table-5.5) } \\
\hline & & $\mathrm{N}$ & $\%$ \\
\hline Cases & Valid & 372 & 100.0 \\
\hline & Excluded $^{\mathrm{a}}$ & 0 & .0 \\
\hline . & Total & 372 & 100.0 \\
\hline
\end{tabular}

Table 5.5:-indicates the results on 372 valid respondents and its $100 \%$ validity in form of case processing summary

\begin{tabular}{|c|c|c|}
\hline \multicolumn{2}{|c|}{ Reliability Statistics(Table-5.6) } & \\
\hline Cronbach's Alpha & N of Items \\
\hline & 0.651 & 12 \\
\hline
\end{tabular}

Table 5.6:-indicates that $\mathrm{N}$ is 12 and Cronbach alpha is 0.651 It means $65.1 \%$ internal consistency amongst SU1-12.

5.1.4 Scale Reliability Appropriateness (A)

\begin{tabular}{|c|c|c|c|}
\hline \multicolumn{4}{|c|}{ Case Processing Summary(Table-5.7) } \\
\hline & & $\mathrm{N}$ & $\%$ \\
\hline \multirow[t]{3}{*}{ Cases } & Valid & 371 & 99.7 \\
\hline & Excluded $^{\mathrm{a}}$ & 1 & .3 \\
\hline & Total & 372 & 100.0 \\
\hline
\end{tabular}

Table 5.7:-indicates the results on 372 valid respondents and its 100\% validity in form of case processing summary

\begin{tabular}{|l|l|l|}
\hline \multicolumn{2}{|c|}{ Reliability Statistics(Table-5.8) } \\
\hline Cronbach's Alpha & N of Items \\
\hline
\end{tabular}

Table 5.8:-indicates that $74.7 \%$ internal consistency amongst A1-12. 


\subsubsection{Scale Reliability CRM: The Business Focus (CRMBF)}

\begin{tabular}{|l|l|r|r|}
\hline \multicolumn{3}{|c|}{ Case Processing Summary(Table-5.9) } \\
\hline \multicolumn{2}{|c|}{ N } & \multicolumn{1}{c|}{$\%$} \\
\hline Cases & Valid & 372 & 100.0 \\
\hline & Excluded $^{\text {a }}$ & 0 & .0 \\
\hline & Total & 372 & 100.0 \\
\hline a. List wise deletion based on all variables in the procedure. & \multicolumn{2}{c}{} \\
\hline
\end{tabular}

Table 5.9:-indicates the results on 372 valid respondents and its $100 \%$ validity in form of case processing summary

\begin{tabular}{|c|c|}
\hline \multicolumn{2}{|c|}{ Reliability Statistics(Table-5.10) } \\
\hline Cronbach's Alpha & N of Items \\
\hline
\end{tabular}

Table 5.10:-indicates that $\mathrm{N}$ is 12 and Cronbach alpha is 0.624 It means $62.4 \%$ internal consistency amongst

\section{CRMBF1-12}

Thus, it can be concluded that the variables entered for scale reliability test are found all valid (58) Cronbach alpha is registered in the range of 0.609 to 0.826 .(i.e. $60.9 \%$ to $82.6 \%$ ). The researcher can move for the further investigation by looking to the above results described from table-5.1 to 5.10.

\subsection{Pearson Correlation Test}

In this study, Pearson correlation test is conducted to determine the relationship amongst the factors i.e. IQ,SU, A and CRMBF. Correlations

\begin{tabular}{|c|c|c|c|c|c|c|}
\hline & & IQ & SQ & SU & $\mathrm{A}$ & CRMBF \\
\hline \multirow[t]{3}{*}{ IQ } & Pearson Correlation & 1 & $.618 * *$ & $.735^{* *}$ & $.678^{* * *}$ & $.612^{* * *}$ \\
\hline & Sig. (2-tailed) & & .000 & .000 & .000 & .000 \\
\hline & $\mathrm{N}$ & 372 & 372 & 372 & 372 & 372 \\
\hline \multirow[t]{3}{*}{ SQ } & Pearson Correlation &. $.618 *$ & 1 & $.654^{* *}$ & $.669^{* * *}$ & $.650 * *$ \\
\hline & Sig. (2-tailed) & .000 & & .000 & .000 & .000 \\
\hline & $\mathrm{N}$ & 372 & 372 & 372 & 371 & 372 \\
\hline \multirow[t]{3}{*}{$\mathrm{SU}$} & Pearson Correlation & $.735^{* *}$ & $.654^{* * *}$ & 1 & $.650^{* *}$ & $.608^{*}$ \\
\hline & Sig. (2-tailed) & .000 & .000 & & .000 & .000 \\
\hline & $\mathrm{N}$ & 372 & 372 & 372 & 371 & 372 \\
\hline \multirow[t]{3}{*}{$\mathrm{A}$} & Pearson Correlation & $.678^{* *}$ & $.769^{* *}$ & $.650^{* *}$ & 1 & $.709^{* * *}$ \\
\hline & Sig. (2-tailed) & .000 & .000 & .000 & & .000 \\
\hline & $\mathrm{N}$ & 371 & 371 & 371 & 371 & 371 \\
\hline \multirow[t]{3}{*}{ CRMBF } & Pearson Correlation & $.612^{* *}$ & $.669^{* *}$ & $.608^{*}$ & $.709^{* *}$ & 1 \\
\hline & Sig. (2-tailed) & .000 & .000 & .000 & .000 & \\
\hline & $\mathrm{N}$ & 372 & 372 & 372 & 371 & 372 \\
\hline
\end{tabular}

**. Correlation is significant at the 0.01 level (2-tailed).

\subsection{Finding}

This study provides outcomes on CRM-ERP integration with special reference to Engineering companies of Ahmedabad City. This study provides insights on employee perception towards CRM activities by focusing on firm business and core components of ERP software in terms of information quality, system quality, system use and appropriateness. The motivational factor of this investigation is to understand digital world in Engineering companies which either SMEs or non-corporate organizations in City of Ahmedabad. The relation between employee perception and effects on firm performance on implementing integration of CRM-ERP will provide directions to employers for better outcomes on productivity.

\subsection{Recommendations}

1. Employees of Engineering companies should focus on up gradation of employee technological knowledge through on the job or off the job trading. 
2. ERP-CRM integration usage should be made more popular amongst the employees of Engineering SMEs with a view to improve interdepartmental communication by enabling disparate departments to collaborate more easily.

3. ERP-CRM integration usage should be made more popular amongst the employees of Engineering SMEs with a view to drive profitability in a better manner.

4. ERP-CRM integration usage should be made more popular amongst the employees of Engineering SMEs with a view to become more customer focused.

5. ERP-CRM integration usage should be made more popular amongst the employees of Engineering SMEs with a view to make more informed business decisions.

6. ERP-CRM integration usage should be made more popular amongst the employees of Engineering SMEs with a view to take a business process view.

7. The Engineering SME employers should take measures on determining how ERP-CRM integration can benefit to the end users.

\section{Conclusion:-}

CRM: The Business Focus (CRMBF) factor is observed as significantly correlated with information quality (IQ) It can be concluded that respondents are more conscious on their job execution through ERP -CRM integration in terms of information accuracy, information preciseness, information completeness, information timeliness, Information compatibility, Information understandability, Information volume appropriateness and Information relevancy, collaborative customer relationship, customer problem solution, right choice of customer and installation process of CRM.

CRM: The Business Focus (CRMBF) factor is observed as significantly correlated with system quality (SQ) It can be concluded that respondents are more conscious on their job execution through ERP -CRM integration in terms of, limitations of unauthorized access Ease of system use in ERP, integrated reports, easy navigation to information appropriate style of design for business., transaction security and error free transaction are, right choice of customer and installation process of CRM.

CRM: The Business Focus (CRMBF) factor is observed as significantly correlated with system quality (SU) It can be concluded that respondents are more conscious on their job execution through ERP -CRM integration in terms of, Job performance improvement, goal achievement, flexible interaction clear and under stable interaction, productivity improvement, technical soundness, easy to access, usage reduces human power in organization, improvement in data control and informational decisions are ,right choice of customer and installation process of CRM, the best customization, time saving, and improving customer services

CRM: The Business Focus (CRMBF) factor is observed as significantly correlated with appropriateness (A) It can be concluded that respondents are more conscious on their job execution through ERP -CRM integration in terms of, improving absenteeism management, improving training and development functions, improving reward management, improves profit ratio and improving data input process, are right choice of customer and installation process of CRM, the best customization, time saving, and improving customer services.

\section{References:-}

1. Kothari, C.R., 2004. Quantitative Techniques, New Delhi, Vikas Publishing House Pvt. Ltd., p.64, 1978.

2. Saccomano, A. (2003). ERP vendors consolidate. Journal of Commerce, 4(24), 46

3. Saunders, M.N.K., \& Lewis, P. (2011). Doing Research in Business and Management. Harlow, United Kingdom: Pearson

4. Seddon PB, 1997, 'A re-specification of the DeLone and McLean model of IS success', Inform Systems Research. Vol.8, No.3, pp. 240-254.

5. System for maintaining process integration', International Journal of Production Research, Vol. 43, No. 19, pp.3959-3982

6. Tabachnick, B.G. and Fidell, L.S. (2007), Using Multivariate Statistics (5th ed.). New York: Allyn and Bacon.

7. Taylor, Mark C. (ed.) (1986). Deconstruction in Context: Literature and philosophy. University of Chicago Press.

8. Taylor, S.A., Hunter, G.H. and Longfellow, T.A. (2006). Testing an expanded attitude model of goal directed behavior in a loyalty context. Journal of Consumer Satisfaction, Dissatisfaction and Complaining Behavior, 19, 
18-39.

9. Thomas H. Davenport and Harris, "Mission Critical - Realizing the Promise of Enterprise Systems" Harvard Business school publishing, (2000).

10. Uden, L. 2007. How to promote competitive advantages for SMEs: issues, ideas and innovation. Journal of Business Systems, Governance and Ethics, 2(2): 1-14.

11. Umble, E.J., Haft, R.R. \& Umble, M.M. (2003). Enterprise resource planning; implementation procedures and critical success factors. European Journal of Operational Research, 146, 241-257. 